\title{
Development of Project Based Psychomotor Assessment Instruments to Measure Student Learning Outcomes in Marketing Subjects on Basic Competencies of Marketing Mix
}

\author{
Eva Rosita Dewi, Wening Patmi Rahayu \\ Program of Business Education, Universitas Negeri Malang \\ E-mail: wening.patmi.fe@um.ac.id
}

\begin{abstract}
This study aimed to produce a project-based psychomotor assessment instrument in accordance with the 2013 curriculum, on Marketing Mix Competence and to measure student learning outcomes. A research method that was used in this article is Research and Development (R\&D). The data was obtained from validation experts, students' understanding of 12 students, as well as student learning outcomes. The validation result of the contents of psychomotor assessment instruments by expert validators which consist of 1 lecturer and 2 teachers are 94 percent and 92.8 percent. Meanwhile, validation of the project by expert validators is about 95 percent and 93.8 percent, respectively. The results of readability test (comprehension) obtained by the students of tenth-grade of Online Business and Marketing Expertise class with 90.2 percent. While the results of student learning in the product label sketch with an average final score of 3.82. Based on the results of content validation and readability test it can be concluded that the project-based psychomotor assessment instrument to measure student learning outcomes is feasible to be used in the teaching-learning process.
\end{abstract}

Keywords: psychomotor assessment, project assessment, learning outcomes, marketing mix

\section{INTRODUCTION}

Knowledge and technology in Indonesia have continue to grow rapidly, therefore it needs to be balanced with quality human resources (Chlivickas, 2014). One of them is quality human resources, namely the education path. Education plays critical role to educate the nation (Marin, 2014). Thus, the existence of education can shape humans to the fullest stated that the various efforts that have been taken by the government in improving the quality of education in Indonesia are the existence of the 2013 education curriculum policy. Able to enrich students' understanding that is valid. Authentic assessment in the 2013 curriculum consists of several aspects, namely cognitive aspects, affective aspects, and psychomotor aspects. However, in an authentic assessment of students' psychomotor aspects, project appraisal can be carried out. Psychomotor aspects are aspects related to skills or ability to act after a person receives a particular learning experience.

Project appraisal is an assignment or investigation carried out by students individually or in groups within a specified time. Project appraisal is useful when used to assess general investigative skills for the implementation of the learning process. Assessment is intended to find out again whether the objectives set have been achieved and whether the learning process has taken place effectively to obtain learning outcomes. Learning outcomes are the achievement of the goals of education for students in following the teaching and learning process. 
Based on the results of interviews with marketing teachers at SMK Negeri 2 Kediri, the assessment in the subjects of Marketing Marketing Class X competencies in the competence of Online and Marketing Business expertise still emphasizes the assessment of knowledge and attitudes hence they are not in accordance with authentic assessment. Overall assessment in the learning process is only generally applied. Therefore, the assessment is carried out in only a few aspects. Project-based psychomotor assessments have not been widely carried out. The assessment used is still using a test form through daily tests, midterm replications, quizzes, and end of semester tests. In addition, psychomotor assessment is still subjective that make it is not maximal. The teacher assesses that grade $\mathrm{X}$ students of online business and marketing expertise are still using conventional assessment. Thus the need for project-based psychomotor assessment instruments in accordance with the 2013 curriculum therefore scoring is easy to understand by teachers and students. In addition, the teacher is easy to assess students objectively in making an assessment.

Project appraisal is suitable for marketing subjects of marketing mix competencies because it can involve students in solving problems and students can be independent in the learning process. The design of this study is supported by several journals, Development of Authentic Project-Based Assessment to Measure Class VII Student Learning Outcomes in thermal themes. The results show that authentic project-based assessment developed based on the five-dimensional framework for authentic assessment is suitable for use. The title Development of Vocational Science Learning with Project-Based Contextual Models to Improve Student Learning Outcomes and Science Process Skills. The results showed that in the science learning model, project-based contextual models developed an increase in scores and were suitable for use. The purpose of this study was to produce project-based psychomotor assessment instruments that are in accordance with the 2013 curriculum on Marketing subjects that are valid and appropriate for marketing mix competencies to be used for assessment guides and to measure the learning outcomes of X grade students of Online and Marketing Business expertise.

\section{METHOD}

This research was carried out by class X students of Online Business and Marketing skills in SMK Negeri 2 Kediri totalling 12 students. Sources of data obtained from, 1) results of questionnaires; 2 ) the task of sketching the product label. This study uses research and development (Research and Development) methods which has been modified to five due to limited costs, facilities and time. The stages of research and development carried out in this study are as follows:

\section{Research and development procedures}

The activities developed in the literature study are studying the theory of projectbased psychomotor assessment instruments to measure learning outcomes in Marketing subjects the basic competencies of the marketing mix. The marketing mix based on the 2013 curriculum in class X contains KI (Core Competence) and KD (Basic Competency) to implement a marketing mix strategy in which there is product material, which explains the labelling of a product. The existence of a 
project-based psychomotor assessment instrument is expected to be able to know student learning outcomes and the teacher can objectively assess students.

\section{Planning}

Planning is the next step after literature study, where researchers develop a product design project based psychomotor assessment instrument. Product designs that will be developed include at least; purpose of product use, who is the user of the product, description of product components and their use. The purpose of product use needs to be formulated as clearly and concretely as possible.

\section{Development of Project Based Psychomotor Instruments}

The steps for developing project-based psychomotor instruments in this study are Preparation of Project-Based Psychomotor Assessment Instruments

The stages in the preparation of project-based psychomotor assessment instruments are: (1) Product specifications, Project-based psychomotor assessment instruments developed are project appraisal instruments wherein the assessment instruments are preface, table of contents, instructions for using psychomotor assessment instruments, psychomotor assessment instructions, student worksheets, project assessment instruments (label sketching), project questions, answer keys, project assessment rubric, calculation of project value, and project appraisal answer criteria;(2) Preparation of instrument lattice, Instrument lattice is created to determine the material to be included in the project assignment. Projectbased psychomotor instrument grids are arranged in the basic competencies of the marketing mix about the form of label sketches that match the product; (3) Preparation of project appraisal, Preparation of project appraisal in the form of skill or psychomotor assignments for students who undertake projects to sketch product labels with stages that include: preparation, processing up to reporting; (4) Preparation of assessment criteria, Psychomotor assessment criteria can be used with an assessment instrument in the form of a checklist and rating scale; (5) Preparation of assessment guidelines, Preparation of assessment guidelines to determine guidelines or references in project-based psychomotor assessments. This project-based psychomotor assessment is used to measure student learning outcomes and facilitate teacher assessment in assessing students who have been achieved; (6) Preparation of usage instructions, The preparation of usage instructions aims to facilitate teachers in the reference or guidelines for carrying out project-based psychomotor assessments hence in assessing students can be objective.

\section{Presentation of instruments}

The presentation of the instrument is the last stage in project-based psychomotor assessment activities compiled with the parts of the instrument being tested, then improved therefore it can be used to a maximum is Content validation, Validation of project-based psychomotor assessment instruments in research and development is content validation (instruments and questions) by experts, expert No. 1 Business Education/Business Administration lecturer and expert No. 2 marketing teachers. The purpose of the validator is to determine the quality of project-based psychomotor assessments that were developed before limited trials. Validation of 
project-based psychomotor assessment instruments to determine the feasibility of the content and language used.

\section{Limited trial test}

The limited product-based psychomotor assessment instrument products were tested at SMK Negeri 2 Kediri in class X students of Online and Marketing Business expertise competencies totalling 12 students. This is intended to find out the learning outcomes of students who obtained increased or decreased. The students' understanding results were collected using a Likert scale questionnaire sheet which was accompanied by an explanation.

\section{Revised Test Results}

The revision of the trial results was carried out after the trial was limited to a project-based psychomotor assessment instrument to improve the initial product. The revision is carried out in accordance with the shortcomings and errors in the project-based psychomotor assessment instrument. The revision of the projectbased psychomotor assessment instrument was carried out based on the results of content validation analysis and readability (understanding) tests that had been carried out by students.

\section{Product Trial}

The product trial aims to collect valid information and the feasibility of a projectbased psychomotor assessment instrument in the Marketing subject of the basic competencies of the marketing mix are : (1) Trial Design, In the product trial research, the content validation and limited trial were carried out. The content validation was carried out with the aim to provide the project-based psychomotor assessment instrument to the validator. While the limited trial can be carried out by providing project-based psychomotor assessment instruments to class X students of Online Business and Marketing competence in SMK Negeri 2 Kediri to determine the readability test.; (2) Try out Subject, The subjects of the trials in research and development were students of class X Online and Marketing Business expertise competencies in SMK Negeri 2 Kediri totalling 12 students. The criteria used as the test subjects were 4 students who had good learning achievement, 4 students who had moderate learning achievement, and 4 students who had low learning achievement as seen from the students' learning outcomes in the previous basic competencies in the same subject; (3) Data Type, This type of data is obtained in the research and development of psychomotor assessment as follows: Quantitative data in the form of numbers are in the form of Likert scales 5, 4, 3, 2, 1 for limited trials obtained from content validation, and readability (comprehension) tests on projectbased psychomotor assessment instruments conducted by students on the results of filling in the instrument sheet project-based psychomotor assessment and Qualitative data are data in the form of comments, suggestions, inputs on projectbased psychomotor assessment instruments obtained from the results of content validation, limited trials, and trials of readability (understanding).

Research and development use questionnaires to collect information or data. The questionnaire was conducted using a Likert scale of 5, 4, 3, 2, 1 with criteria that 
can be seen in Table 1 for content validation (instruments and questions) while Table 2 for the readability test criteria (understanding).

Table 1. Questionnaire Criteria for Validation of Content

\begin{tabular}{cl}
\hline Score & \multicolumn{1}{c}{ Explanation } \\
\hline 5 & Very suitable / very interesting / very feasible / very easy / very appropriate \\
4 & Appropriate / interesting / decent / easy / right \\
3 & Quite appropriate / quite interesting / quite decent / quite easy / quite right \\
2 & Less appropriate / less attractive / less feasible / less easy / less precise \\
1 & Not appropriate / not attractive / not feasible / not easy / not appropriate
\end{tabular}

Source: Authors (2018)

Table 2. Questionnaire Criteria for Readability Test (Understanding) of Project Based Psychomotor Assessment Instruments

\begin{tabular}{cl}
\hline Score & \multicolumn{1}{c}{ Explanation } \\
\hline 5 & Very suitable / very interesting / very easy / very appropriate \\
4 & Appropriate / interesting / easy / right \\
3 & Quite appropriate / quite interesting / quite easy / quite appropriate \\
2 & Less suitable / less attractive / less easy / less precise \\
1 & Not suitable / not interesting / not easy / inappropriate \\
\hline
\end{tabular}

Source: Authors (2018)

Data Analysis Techniques obtained from experts were analyzed using percentage descriptive techniques. The descriptive percentage is to convert quantitative data into percentage forms to be interpreted into qualitative data. Based on (Suparti, 2016) a formula is obtained to calculate the percentage as follows:

$\mathrm{P}=\frac{\sum X}{\sum X 1} \times 100 \%$

\section{Explanation:}

$\mathrm{P} \quad=$ Percentage

$\sum \mathrm{X} \quad=$ Number of scores obtained

$\sum \mathrm{X}=$ Maximum score amount

$100 \%=$ Constants

Feasibility criteria analysis of the percentage of development products can be presented in Tables 3 and 4 .

Table 3. Criteria for Validity of Content of Project-Based Psychomotor Assessment Instruments

\begin{tabular}{cl}
\hline $\begin{array}{c}\text { Eligibility Criteria } \\
\text { (Percentage) }\end{array}$ & \multicolumn{1}{c}{ Validation Criteria } \\
\hline $\mathbf{8 1 \%}-\mathbf{1 0 0 \%}$ & Very Decent (without revision) \\
$\mathbf{6 1 \%}-\mathbf{8 0 \%}$ & Eligible (can be used but there needs to be a minor revision) \\
$\mathbf{4 1 \% - 6 0 \%}$ & Inadequate (may be used but need major revisions) \\
$\mathbf{2 1 \% - 4 0 \%}$ & Not Eligible (may not be used) \\
$\mathbf{0 \% - 2 0 \%}$ & Very inappropriate (may not be used) \\
\hline
\end{tabular}

Source: Adapted from Akbar (2013) 
Table 4. Criteria for Readability (Understanding) of Project-Based Psychomotor Assessment Instruments

\begin{tabular}{cl}
\hline $\begin{array}{c}\text { Eligibility Criteria } \\
\text { (Percentage) }\end{array}$ & \multicolumn{1}{c}{ Validation Criteria } \\
\hline $\mathbf{8 1 \% - 1 0 0 \%}$ & Very Suitable / very easy to understand (without any revisions) \\
$\mathbf{6 1 \% - 8 0 \%}$ & $\begin{array}{l}\text { Appropriate/ easy to understand (can be used but need minor } \\
\text { revisions) }\end{array}$ \\
$\mathbf{4 1 \% - 6 0 \%}$ & $\begin{array}{l}\text { Less suitable / less easy to understand (may be used but need } \\
\text { major revisions) }\end{array}$ \\
$\mathbf{2 1 \% - 4 0 \%}$ & Not suitable / not easily understood (may not be used) \\
$\mathbf{0 \% - 2 0 \%}$ & Very inappropriate / not very easy to understand (may not be \\
& used) \\
\hline
\end{tabular}

Source: Adapted from Akbar (2013)

After each item criterion is known, it can be determined whether the item needs to be revised or not. Suggestions from validators, teachers and students' level of understanding also determine whether or not the revision is implemented. Qualitative data techniques from expert lecturers, teachers, and the results of the test analysis of the readability (understanding) of students in the form of comments, suggestions, input. The results of qualitative data analysis in the form of comments, suggestions and input will be described in a brief narrative. Even though the item is declared feasible, the advice given by the expert lecturer and teacher validator must be used in order to improve the project-based psychomotor assessment instrument

\section{RESULTS \& DISCUSSION Result}

Products produced in research and development are project-based psychomotor assessment instruments to measure student learning outcomes in Marketing subjects basic competencies in the marketing mix in class X Online Business and Marketing expertise competencies at SMK Negeri 2 Kediri. Psychomotor assessment instruments are assessment instruments for assessing the practices carried out by students, so students know their abilities. This psychomotor instrument includes (1) instructions for use; (2) assessment instructions; (3) grid of psychomotor assessment instruments; (4) student worksheets; (5) work steps; (6) project questions; and (7) project assessment criteria. This research and development through two stages of testing, namely content validation and limited trials. The data obtained can be presented as follows.

Data from the content validation of psychomotor assessment instruments were obtained from filling out the validation sheet by the 1st expert validator (lecturer) and the second expert validator (teacher). Quantitative data on the results of content validation by the 1st expert validator (lecturer) and 2nd (teacher) on the psychomotor assessment instrument are directly used to determine the percentage of instrument feasibility. Quantitative data are the results of the content validation by the 1 st expert validator (lecturer) and 2 nd (teacher) to get a score (X). Where the score obtained will be used to calculate the percentage of the feasibility of psychomotor assessment instruments. Based on the results of the validation of the contents of psychomotor assessment instruments on 14 items components by the 
1st expert validator (lecturer) obtained an average score of 4.7 with a percentage of 94 percent and the second expert validator (teacher) obtained an average score of 4.6 with a percentage amounting to 92.8 percent.

In addition to quantitative data validation, the content of the project-based psychomotor assessment instrument uses qualitative data in the form of comments, suggestions and input given the 1st expert validator (lecturer) and 2 (teacher) to improve the instrument. The following qualitative data gave the 1 st expert validator (lecturer) and the second (teacher) on the project-based psychomotor assessment instruments can be seen in Table 5 .

Table 5. Qualitative Data on Validation Results Contents of Project-Based Psychomotor Assessment Instruments

\begin{tabular}{lcll}
\hline No & Validator & & \multicolumn{1}{c}{ Comments and Suggestions } \\
\hline 1. & Validator 1 & 1. & Good and complete instrument \\
& & 2. & Overall, it's good \\
2. & Validator 2 & 1. & $\begin{array}{l}\text { Products made are already good and suitable for use } \\
\end{array}$ \\
& & 2. & $\begin{array}{l}\text { Good psychomotor assessment materials and instruments } \\
\text { are very helpful in use because language is easy to } \\
\end{array}$ \\
& & \\
\hline
\end{tabular}

While the validation of the project question sketching the label was done to see the feasibility of the project in the psychomotor assessment instrument. Quantitative data to find out the results of the validation of the project questions were carried out by the 1st expert validator (lecturer) and 2nd (teacher). Quantitative data to determine the scores obtained from the 1st expert validator (lecturer) and 2nd (teacher). Where the score obtained is done to calculate the percentage of the feasibility of psychomotor assessment instruments. Based on the results of the validation of the project questions, labelling sketches on 13 items of components by the 1st expert validator (lecturer) obtained an average score of 4.8 with a percentage of 95 percent and the second (teacher) obtained an average score of 4.6 with a percentage of 93.8 percent.

In addition to quantitative data the validity of project questions using qualitative data, the results of the validation of the project questions make a label sketch can be seen in Table 6.

Table 6. Qualitative Data on Validation Results for Project Problems Sketching Labels

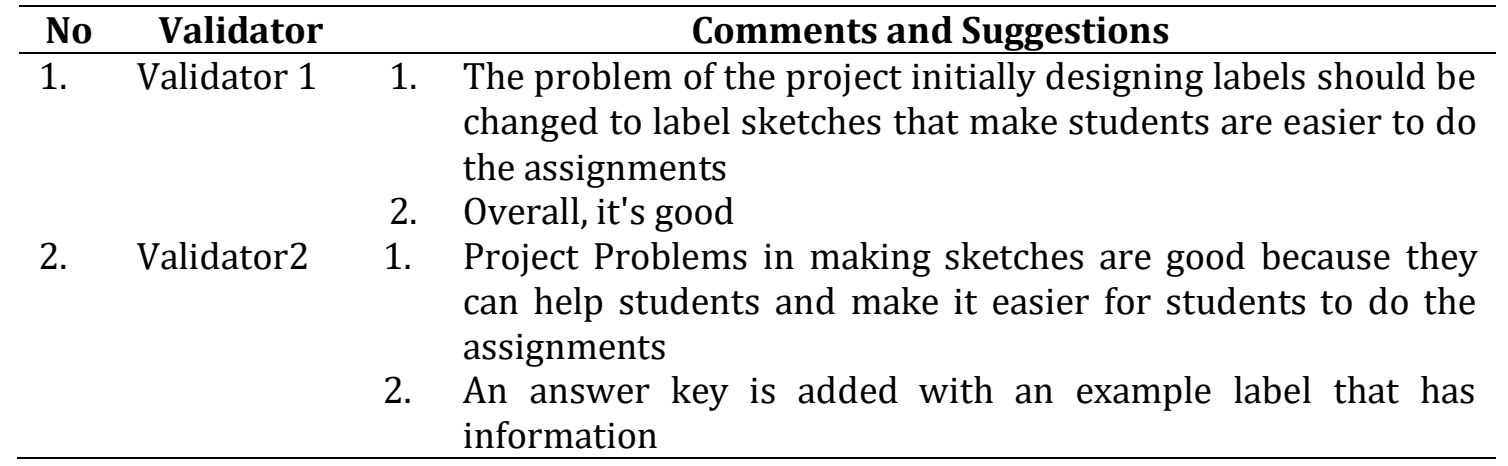


Thus, it can be concluded that psychomotor assessment instruments can be said to be "very feasible". However, it needs to be improved to be better and perfect. Limited try out of psychomotor assessment instruments which are to read (understand) the project-based psychomotor assessment instruments to be tested by class $\mathrm{X}$ students of online business and marketing competence. Psychomotor assessment instruments were tested in the form of assignments to label sketches. Limited trials were carried out in 12 Kediri State Vocational Schools 2. Readability test (understanding) of a project-based psychomotor assessment instrument is carried out to determine the level of students' understanding of the questions on a project-based psychomotor assessment instrument on content and language conducted in terms of the use of the instrument, namely students.

Data obtained from the readability test (understanding) psychomotor assessment instruments in the form of questionnaires. Readability test results (understanding) of psychomotor assessment instruments on 8 items components by students obtained an average score of 90.2 percent means that psychomotor assessment instruments can be understood by students and stated "very appropriate / very interesting / very easy to understand. The 12 students stated that the assignments were very easy to understand and understand so students could do project problems easily and well.

\section{Discussion}

Assessment and learning outcomes are things that cannot be separated from the learning process (Safaroh \& Dewi, 2017). Learning outcomes can be measured by giving assignments to students. The assignment is in the form of project questions regarding label sketches. With the task of skill, students can become more creative and independen (Amponsah et al., 2018; Kashani-Vahid et al., 2017; Wechsler et al., 2018). This study can be seen that the project-based psychomotor assessment instrument can measure the learning outcomes of class $\mathrm{X}$ students of Online Business and Marketing competence at SMK Negeri 2 Kediri. At the time of limited testing, there were 12 students divided into three groups and made label sketches and group presentations. Based on the value of the components obtained with an average of 95.76 and the average final score of 3.82. Student learning outcomes of project-based psychomotor assessment instruments can be said to be very good and get the title A. Thus it can be concluded that almost most students like the existence of innovation in learning (Sandberg and Ohman, 2011), especially involving the activeness and creativity of students and direct involvement with experience (Mynbayeva et al., 2016; Richardson \& Mishra, 2018).

\section{CONCLUSION}

Based on the results of the research project-based psychomotor assessment instruments that are developed have a quality that is feasible to be used in the learning process. The development of project-based psychomotor assessment instruments can produce instruments that are in accordance with the 2013 curriculum on Marketing subjects, the basic competencies of the marketing mix, and can be used to measure student learning outcomes. This research and development 
are carried out with content validation and readability (understanding) test. The results of the validation of the contents of the psychomotor assessment instrument by the 1st expert validator (lecturer) showed 94 percent and the second expert (teacher) 92.8 percent. As well as the validation of the 1st expert validator project question (lecturer) shows 95 percent and second expert (teacher) 93.8 percent. Readability test results show 90.2 percent. While student learning outcomes show an average score of 3.82 .

\section{REFERENCES}

Akbar, S. 2013. Instrumen Perangkat Pembelajaran. Bandung: PT Remaja Rodakarya. Amponsah, S., Kwesi, A.B., \& Ernest, A. 2018. Lin's creative pedagogy framework as a strategy for fostering creative learning in Ghanaian schools. Thinking Skills and Creativity 31,11-18. https://doi.org/10.1016/j.tsc.2018.09.002

Chlivickas, E. 2014. International Cooperation and Innovations for Developing Human Resources System. Procedia - Social and Behavioral Sciences, The 2dn International Scientific conference Contemporary Issues in Business, Management and Education 2013 110, 276-283. https://doi.org/10.1016/j.sbspro.2013.12.871

Hayati, M.N., Supardi, K.I., \& Miswadi, S.S. 2013. Pengembangan Pembelajaran IPA SMK Dengan Model Kontekstual Berbasis Proyek Untuk Meningkatkan Hasil Belajar dan Kerampilan Proses SAINS Siswa. E-Journal Universitas Negeri Semarang, 2(1), 53-58.

Kashani-Vahid, L., Afrooz, G., Shokoohi-Yekta, M., Kharrazi, K., Ghobari, B., 2017. Can a creative interpersonal problem solving program improve creative thinking in gifted elementary students? Thinking Skills and Creativity 24, 175-185. https://doi.org/10.1016/j.tsc.2017.02.011

Marin, S. 2014. Assessing the Quality of the Psycho-pedagogical Programmes Training Human Resources in Education. Procedia - Social and Behavioral Sciences, International Scientific Conference "Sports, Education, Culture Interdisciplinary Approaches in Scientific Research", 2013, "Dunarea de Jos" University of Galati, Romania 137, 132-137. https://doi.org/10.1016/j.sbspro.2014.05.265

Mynbayeva, A., Vishnevskay, A., \& Sadvakassova, Z. 2016. Experimental Study of Developing Creativity of University Students. Procedia - Social and Behavioral Sciences, Future Academy Multidisciplinary Conference "ICEEPSY \& CPSYC \& icPSIRS \& BE-ci" 13-17 October 2015 Istanbul 217, 407-413. https://doi.org/10.1016/j.sbspro.2016.02.113

Richardson, C., \& Mishra, P. 2018. Learning environments that support student creativity: Developing the SCALE. Thinking Skills and Creativity, 27, 45-54. https://doi.org/10.1016/j.tsc.2017.11.004

Sandberg, K.W., \& Ohman, G. 2011. Learning in Innovation Development. Procedia Social and Behavioral Sciences, World Conference on Educational $\begin{array}{lllll}\text { Technology Researches } & 2011 \quad 28, & \text { 379-383. }\end{array}$ https://doi.org/10.1016/j.sbspro.2011.11.072 
Safaroh, R., \& Dewi, N.R. 2017. Pengembangan Asesmen Autentik Berbasis Proyek untuk Mengukur Hasil Belajar Siswa Kelas VII pada Tema Panas. E-Journal Universitas Negeri Semarang, 46(1), 41-50.

Wechsler, S.M., Saiz, C., Rivas, S.F., Vendramini, C.M.M., Almeida, L.S., Mundim, M.C., \& Franco, A. 2018. Creative and critical thinking: Independent or overlapping components? Thinking Skills and Creativity 27, 114-122. https://doi.org/10.1016/j.tsc.2017.12.003 